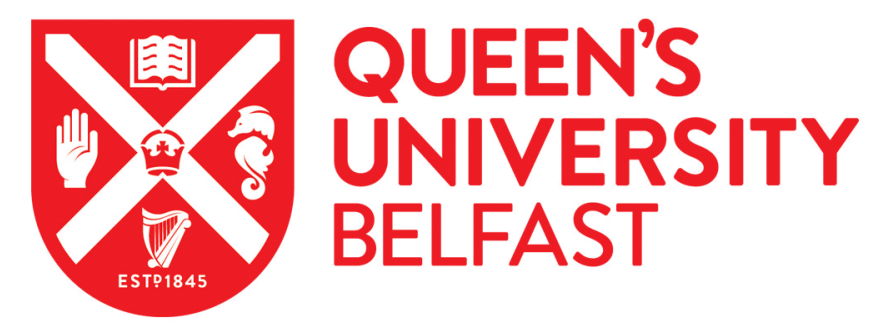

\title{
Leaf inputs from invasive and native plants drive differential mosquito abundances
}

Cuthbert, R. N., Dalu, T., Mutshekwa, T., \& Wasserman, R. J. (2019). Leaf inputs from invasive and native plants drive differential mosquito abundances. Science of the Total Environment.

https://doi.org/10.1016/j.scitotenv.2019.06.470

Published in:

Science of the Total Environment

Document Version:

Peer reviewed version

Queen's University Belfast - Research Portal:

Link to publication record in Queen's University Belfast Research Portal

Publisher rights

Copyright 2019 Elsevier.

This manuscript is distributed under a Creative Commons Attribution-NonCommercial-NoDerivs License

(https://creativecommons.org/licenses/by-nc-nd/4.0/), which permits distribution and reproduction for non-commercial purposes, provided the author and source are cited.

\section{General rights}

Copyright for the publications made accessible via the Queen's University Belfast Research Portal is retained by the author(s) and / or other copyright owners and it is a condition of accessing these publications that users recognise and abide by the legal requirements associated with these rights.

Take down policy

The Research Portal is Queen's institutional repository that provides access to Queen's research output. Every effort has been made to ensure that content in the Research Portal does not infringe any person's rights, or applicable UK laws. If you discover content in the Research Portal that you believe breaches copyright or violates any law, please contact openaccess@qub.ac.uk. 


\section{Accepted Manuscript}

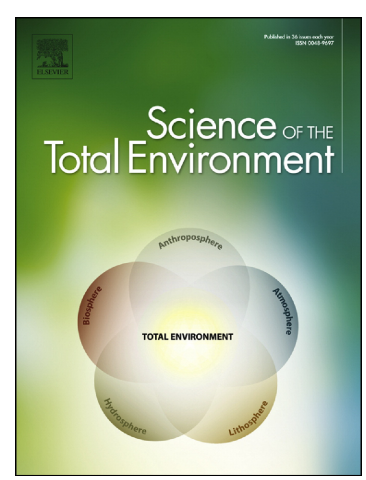

Ross N. Cuthbert, Tatenda Dalu, Thendo Mutshekwa, Ryan J. Wasserman

Leaf inputs from invasive and native plants drive differential mosquito abundances

PII: S0048-9697(19)33044-X

DOI: https://doi.org/10.1016/j.scitotenv.2019.06.470

Reference: STOTEN 33124

To appear in: Science of the Total Environment

Received date:

1 June 2019

Revised date:

27 June 2019

Accepted date:

27 June 2019

Please cite this article as: R.N. Cuthbert, T. Dalu, T. Mutshekwa, et al., Leaf inputs from invasive and native plants drive differential mosquito abundances, Science of the Total Environment, https://doi.org/10.1016/j.scitotenv.2019.06.470

This is a PDF file of an unedited manuscript that has been accepted for publication. As a service to our customers we are providing this early version of the manuscript. The manuscript will undergo copyediting, typesetting, and review of the resulting proof before it is published in its final form. Please note that during the production process errors may be discovered which could affect the content, and all legal disclaimers that apply to the journal pertain. 
Leaf inputs from invasive and native plants drive differential mosquito abundances

Ross N. Cuthbert ${ }^{\mathrm{a}, \mathrm{b}, *}$, Tatenda Dalu ${ }^{\mathrm{c}, \mathrm{b}}$, Thendo Mutshekwa ${ }^{\mathrm{c}}$, Ryan J Wasserman ${ }^{\mathrm{d}, \mathrm{b}}$

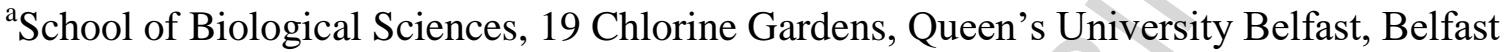
BT9 5DL, Northern Ireland

${ }^{\mathrm{b}}$ South African Institute for Aquatic Biodiversity, Grahamstown 6140, South Africa

${ }^{c}$ Department of Ecology and Resource Management, University of Venda, Thohoyandou 0950, South Africa

${ }^{\mathrm{d}}$ Department of Biological Science and Biotechnology, Botswana International University of Science and Technology, Palapye, Botswana

*Corresponding author, email: rcuthbert03@qub.ac.uk 


\begin{abstract}
Ecological impacts of invasive alien species can be unpredictable and simultaneously span multiple habitat types and taxonomic groups. Invasive alien plants can have particularly severe impacts, and plant inputs into aquatic environments can profoundly alter community composition of invertebrates, such as mosquitoes. Here, we examine larval mosquito colonisation of aquatic containers treated with leaves from four different terrestrial plants: the invasive tickberry Lantana camara, invasive guava Psidium guajava, native sycamore fig Ficus sycomorus and native silver cluster-leaf Terminalia sericea. Larval mosquito abundances differed significantly accordingly to leaf treatment, whilst no mosquitoes colonised leaf-free controls. Leaf litter from the invasive $L$. camara, invasive P. guajava and native $F$. sycomorus drove significant increases in mosquito abundances relative to native $T$. cericea. We demonstrate the importance of plant identity for larval mosquito proliferations in aquatic habitats, with changes in plant community composition following terrestrial plant invasions potentially resulting in increased mosquito abundances. In turn, this may have implications for the vectoring of mosquito-borne disease.
\end{abstract}

\title{
Key words
}

invasive alien plant; plant-vector interactions; container-breeding mosquitoes; leaf litter; vector-borne disease; oviposition 


\section{Introduction}

The ecosystem-level impacts of invasive alien species can be multifaceted, with introductions often driving unexpected consequences in novel ranges. For example, invasive alien species can alter recipient ecosystems through greater provisioning of habitat, increased resource availability and direct interference with consumers (e.g. Green et al., 2011; Kobak et al., 2016; Sheppard et al., 2018). As plants are often the most important energy sources in terrestrial ecosystems, invasive alien plants can have especially marked ecological consequences (Sax et al., 2005), and these effects can span multiple habitat types. In particular, aquatic ecosystems may be heavily impacted by changes to terrestrial vegetation composition due to differences in detrital nutrient properties (Yanoviak, 1999). Indeed, alterations to species-level plant inputs can significantly change invertebrate community dynamics in aquatic habitats, where mosquitoes are often numerically dominant and benefit directly from leaf litter as a resource (Leonard and Juliano, 1995; Yanoviak, 1999; Reiskind et al., 2009). Furthermore, invasive terrestrial plants can provide increased shelter or breeding sites for adult mosquitoes, with potential benefits for population-level fitness and the transmission of mosquito-borne disease (Rajnikant et al., 1992; Webb et al., 2012; Stone et al., 2018). Mosquitoes are known to be highly responsive to plant cues when ovipositing (Shaalan and Canyon, 2018), and an increasing body of evidence suggests that some invasive alien plant species may enhance mosquito demographics and exacerbate disease risk (Reiskind et al., 2010; Mack and Smith, 2011). However, understanding differential colonisation responses of mosquitoes among plant species has remained elusive.

In the present study, we examine the effects of leaf litter inputs from two invasive and two native terrestrial plant species on larval mosquito abundances (Culex spp. and Aedes spp. combined): the invasive tickberry Lantana camara, invasive guava Psidium guajava, native sycamore fig Ficus sycomorus and native silver cluster-leaf Terminalia sericea. The $L$. 
camara species complex is native to tropical central and southern America, and is known to impact ecosystems through excessive resource additions, alterations to fire regimes and increased erosion (Richardson and van Wilgen, 2004; Vardien et al., 2012). Psidium guajava is also native to central and southern America and has substantial negative impacts on native species through competition and replacement (Urquía et al., 2019). Both species are recognised as invasive in South Africa and known to colonise close to waterbodies, whilst the two native plants serve as representative resident species.

\section{Materials and Methods}

Plant leaves of invasive i.e. L. camara and P. guajava and native i.e. F. sycomorus, and $T$. sericea and were collected in November 2018 by hand from trees along Muvudi River riparian zone ( $\left.22^{\circ} 58.967^{\prime} \mathrm{S} 30^{\circ} 26.840^{\prime} \mathrm{E}\right)$ in Thohoyandou, Limpopo province, South Africa, before being air dried at room temperature. Only fresh plant leaves were selected, given many plants reabsorb nutrients prior to senescence (e.g. Staaf 1982). After drying, approximately $3 \mathrm{~g}$ of the material for each species was weighed and added into $5 \mathrm{~L}$ white polyethylene buckets, filled with $3.9 \mathrm{~L}$ of filtered (filter size $63 \mu \mathrm{m}$ ) borehole + river water (70:30 ratio). The initial mean water temperature was $27.2 \pm 0.2^{\circ} \mathrm{C}(\mathrm{SD})$, conductivity was $169.3 \pm 4.0 \mu \mathrm{S} \mathrm{cm}^{-1}$, total dissolved solids were $85.5 \pm 2.6 \mathrm{mg} \mathrm{L}^{-1}$ and $\mathrm{pH}$ was $6.6 \pm 0.1$. Weekly, the buckets were topped up to $3.9 \mathrm{~L}$ with filtered borehole water. The twenty-five 5 L buckets (i.e. 5 replicates $\times 4$ species, +5 controls) were placed in a shaded area on the University of Venda campus in a randomised array, and mosquitoes could freely colonise any bucket. Mosquito larvae counting was initiated after three weeks to allow for colonisation, with first instar stages omitted from counts due to low visual detectability. During each sampling event, container contents were strained, and larval mosquitoes counted before being returned to their respective containers. Container-breeding mosquito larvae (Culex spp. and Aedes spp.) were subsequently enumerated weekly over 4 weeks. 
Generalised linear mixed models (GLMMs) assuming a Poisson error distribution and log link were used to analyse larval mosquito counts over the experimental period according to the treatment and time terms, and their interaction (Brooks et al., 2017). Bucket ID was included as a random effect to account for repeated measures of each bucket over time, with time included as a within-subject variable. Resulting models were tested for zero inflation and overdispersion via simulation comparisons (Hartig, 2018). Analysis of deviance with Type II sums of squares was used to infer significance levels of main effects (Fox and Weisberg, 2011), with estimated marginal means used post-hoc for Tukey comparisons (Lenth, 2018). In all analyses, significance was inferred at $p<0.05$. All statistical analyses were performed using the R environment (v3.5.1; R Development Core Team, 2018).

\section{Results}

No larval mosquitoes were recovered from control groups, and thus this treatment level was removed from further analyses. Contrastingly, mosquitoes colonised all containers treated with leaf litter, however abundances in native $T$. sericea were considerably reduced overall (Fig. 1). The interaction term between treatment and time was not statistically clear (likelihood ratio test: $\chi^{2}=6.66, \mathrm{df}=9, p=0.67$ ), and was thus removed from the final model. Accordingly, differences among leaf treatments in larval abundances were consistent across the monitoring period. Leaf treatments significantly affected larval mosquito abundances (GLMM: $\left.\chi^{2}=61.66, \mathrm{df}=3, p<0.001\right)$. Significantly fewer mosquitoes were present in containers treated with native $T$. sericea as compared to invasive tickberry $L$. camara, invasive guava $P$. guajava and native $F$. sycomorus (all $p<0.001$ ); there were no significant differences among the latter three plant species (all $p>0.05$ ). Larval mosquito abundances also differed significantly over time overall (GLMM: $\left.\chi^{2}=20.23, \mathrm{df}=3, p<0.001\right)$, with abundances falling significantly between the first and fourth week of the monitoring period ( $p$ $<0.001)$ (Fig. 2). 


\section{Discussion}

The establishment and spread of invasive alien species can often have unexpected ecosystemlevel impacts across multiple habitat types. In the present study, we demonstrate that leaf litter inputs among invasive and native terrestrial plants can differ markedly in their effects on larval mosquito abundances. Specifically, two highly invasive terrestrial plant species, $L$. camara and $P$. guajava, and the native $F$. sycomorus, drove significantly elevated mosquito abundances compared to native $T$. sericea. Mosquitoes were entirely absent from leaf-free controls, owing to a lack of organic content. Accordingly, alterations to plant stands following invasions could worsen mosquito problems by driving increases in mosquito abundances, with possible implications for public health. Yet, this effect is likely speciesspecific. Furthermore, plant incursions into previously unvegetated areas in proximity to water bodies could further promote mosquito proliferations.

The complete lack of colonisation of leaf-free controls in the present study is not surprising, given the strong general attractant effect of organic material on gravid mosquitoes (Hazard et al., 1967). Indeed, given the capacity for mosquitoes to exploit small, container-style habitats which are often present in high densities across terrestrial landscapes, there is frequently a high degree of selectivity for 'rewarding' habitats among available patches. Whilst we observed negligible colonisation of native $T$. sericea treated waters, a much stronger attractant effect was found towards native $F$. sycomorus. Accordingly, botanical effects appear to be tightly linked to plant identity, with effects of invasion potentially dependent on background vegetative composition.

Nevertheless, although not assessed in the present study, natural compounds from plants can have lethal effects on larval mosquitoes (Shaalan and Canyon, 2018), and so it cannot be ruled out that these effects altered abundances in specific treatments here, rather than via 
selectivity. Indeed, whilst previous research has demonstrated attraction to $P$. guajava fruits by adult mosquitoes (Müller et al., 2010), compounds from P. guajava and L. camara have demonstrated mosquitocidal properties through lipophilic extracts (Mendes et al. 2017; Hari and Mathew, 2018). Yet, the specific compounds that drive colonisation differences require further investigation. In particular, to our knowledge, no studies have examined effects of compounds from $T$. sericea on mosquito abundances. Given the importance of the identity of plant inputs for the productivity of mosquito populations in aquatic habitats (Reiskind et al., 2009, 2010), quantifications of differential responses among invasive and native plant species is of high importance in the context of public health. Further research should therefore examine the direct effects of these and other plant inputs on additional mosquito life history traits, such as size, sex and fecundity, as well as direct lethal effects. In turn, this may aid in the identification of specific compounds that deter colonisation.

\section{Acknowledgements}

Financial support for this study was granted by the National Research Foundation of South Africa Thuthuka (NRF, UID: 117700) and University of Venda Niche grants (SES/18/ERM/10) to TD. Any opinions, findings, conclusions or recommendations expressed in this material are those of the authors, and the NRF does not accept any liability in this regard. RNC acknowledges funding from the Department for the Economy, Northern Ireland.

\section{References}

Brooks, M.E., Kristensen, K., van Benthem, K.J., Magnusson, A., Berg, C.W., Nielsen, A., Skaug, H.J., Machler, M., Bolker, B.M., 2017. glmmTMB balances speed and flexibility among packages for zero-inflated generalised linear mixed modeling. The R Journal 9, 378-400. 
Fox, J., Weisberg, S., 2011. An R companion to applied regression. Sage. Thousand Oaks, USA.

Green, P.T., O'Dowd, D.J., Abbott, K.L., Jeffery, M., Retallick, K., Mac Nally, R., 2011. Invasional meltdown: Invader-invader mutualism facilitates a secondary invasion. Ecology 92, 1758-1768.

Hari, I., Mathew, N., 2018. Larvicidal activity of selected plant extracts and their combination against the mosquito vectors Culex quinquefasciatus and Aedes aegypti. Environ. Sci. Pollut. Res. Int. 25, 9176-9185.

Hazard, E.I., Mayer, M.S., Savage, K.E., 1967. Attraction and oviposition stimulation of gravid female mosquitoes by bacteria isolated from hay infusions. Mosq. News 27, $133-136$.

Hartig, F., 2018. DHARMa: residual diagnostics for hierarchical (multi-level/mixed) regression models. $\mathrm{R}$ package.

Kobak, J., Poznańska, M., Jermacz, Ł., Kakareko, T., Prądzynski, D., Łodygowska, M., Montowska, K., Bącela-Spychalska, K.,2016. Zebra mussel beds: an effective feeding ground for Ponto-Caspian gobies or suitable shelter for their prey? PeerJ. 4, e2672.

Leonard, P.M., Juliano, S.A., 1995. Effect of leaf litter and density on fitness and population performance of the hole mosquito Aedes triseriatus. Ecol. Entomol. 20, 125-136.

Lenth, R., 2018. emmeans: estimated marginal means, aka least-squares means. R package.

Mack, R., Smith, M., 2011. Invasive plants as catalysts for the spread of human parasites. NeoBiota. 9, 13-29. 
Mendes, L.A., Martins, G.F., Valbon, W.R., de Souza, T.D.S., Menini, L., Ferreira, A., da Silva Ferreira, M.F., 2017. Larvicidal effect of essential oils from Brazilian cultivars of guava on Aedes aegypti L. Ind. Crop Prod. 108, 684-689.

Müller, G.C., Beier, J.C., Traore, S.F., Toure, M.B., Traore, M.M., Bah, S., Doumbia, S., Schlein, Y., 2010. Field experiments of Anopheles gambiae attraction to local fruits/seedpods and flowering plants in Mali to optimize strategies for malaria vector control in Africa using attractive toxic sugar bait methods. Malar. J. 9, 262.

Rajnikant, B.R.M., Sharma, R.C., Gupta, D.K., Gautam, A.S., 1992. Anopheline breeding in ponds of central Gujarat with reference to water hyacinth infestation. Ind. J. Malariol. $29,57-61$.

Reiskind, M., Greene, K., Lounibos, L., 2009. Leaf species identity and combination affect performance and oviposition choice of two container mosquito species. Ecol. Entomol. 34, 447-456.

Reiskind, M., Zarrabi, A., Lounibos, L., 2010. Invasive leaf resources alleviate density dependence in the invasive mosquito, Aedes albopictus. Biol. Inv. 12, 2319-2328.

R Development Core Team., 2018. R: a language and environment for statistical computing. R Foundation for statistical computing, Vienna, Austria.

Richardson, D.M., van Wilgen, B.W., 2004. Invasive alien plants in South Africa: How well do we understand the ecological impacts? S. Afr. J. Sci. 100, 45-52.

Sax, D.F., Stachowicz, J.J., Gaines, S.D., 2005. Species invasions: insights into ecology, evolution, and biogeography. Sinauer Associates Incorporated, Sunderland.

Shaalan, E.A-S., Canyon, D.V., 2018. Mosquito oviposition deterrents. Environ. Sci. Pollut. Res. 25, 10207-10217. 
Sheppard, C.S., Carboni, M., Essl, F., Seebens, H., DivGrass Consortium ., Thuiller, W., 2018. It takes one to know one: Similarity to resident alien species increases establishment success of new invaders. Divers. Distrib. 24, 680-691.

Staaf, H., 1982. Plant nutrient changes in beech leaves during senescence as influenced by site characteristics. Acta Oecol. 3, 161-70.

Stone, C.M., Witt, A.B.R., Walsh, G.C., Foster, W.A., Murphy, S.T., 2018. Would the control of invasive alien plants reduce malaria transmission? A review. Parasit. Vectors $11,76$.

Urquía, D., Gutierrez, B., Pozo, G., Pozo, M.J., Espín, A., de Lourdes Torres, M., 2019. Psidium guajava in the Galapagos Islands: Population genetics and history of an invasive species. PLoS ONE 14, e0203737.

Vardien, W., Richardson, D.M, Foxcroft, L.C., Thompson, G.D., Wilson, J.R.U., Le Roux, J.J., 2012. Invasion dynamics of Lantana camara L. (sensu lato) in South Africa. S. Afr. J. Bot. 81, 81-94.

Webb, C.E., Ironside, A., Mansfield, S., 2012. A comparison of oviposition preference in the presence of three aquatic plants by the mosquitoes Culex annulirostris Skuse and Culex quinquefasciatus (Culicidae: Diptera) in laboratory tests. Gen. App. Entomol. $41,21-26$.

Yanoviak, S.P., 1999. Effects of leaf litter species on macroinvertebrate community properties and mosquito yield in neotropical tree hole microcosms. Oecologia 120, $147-155$. 
Fig. 1. Mean $( \pm S E)$ larval mosquito abundances in 3.9 L containers under four plant leaf treatments (Fs, native Ficus sycomorus; Ts, native Terminalia sericea; Lc, invasive Lantana camara; Pg, invasive Psidium guajava) over four week monitoring period. Letters denote significant differences.

Fig. 2. Mean $( \pm S E)$ weekly larval mosquito abundances in $3.9 \mathrm{~L}$ containers under four plant leaf treatments (Fs, native Ficus sycomorus; Ts, native Terminalia sericea; Lc, invasive Lantana camara; Pg, invasive Psidium guajava) over four week monitoring period. Locallyweighted scatterplot smoothing lines are presented (9/10 smoother span) to illustrate trends. 


\section{Highlights}

- Mosquito colonisation under invasive and native leaf litter treatments examined.

- No mosquitoes colonised leaf-free control aquatic habitats.

- Significant differences were found among invasive and native plant species.

- Mosquitoes significantly avoided native Terminalia sericea.

- Terrestrial plant invasion impacts can span multiple habitat types. 


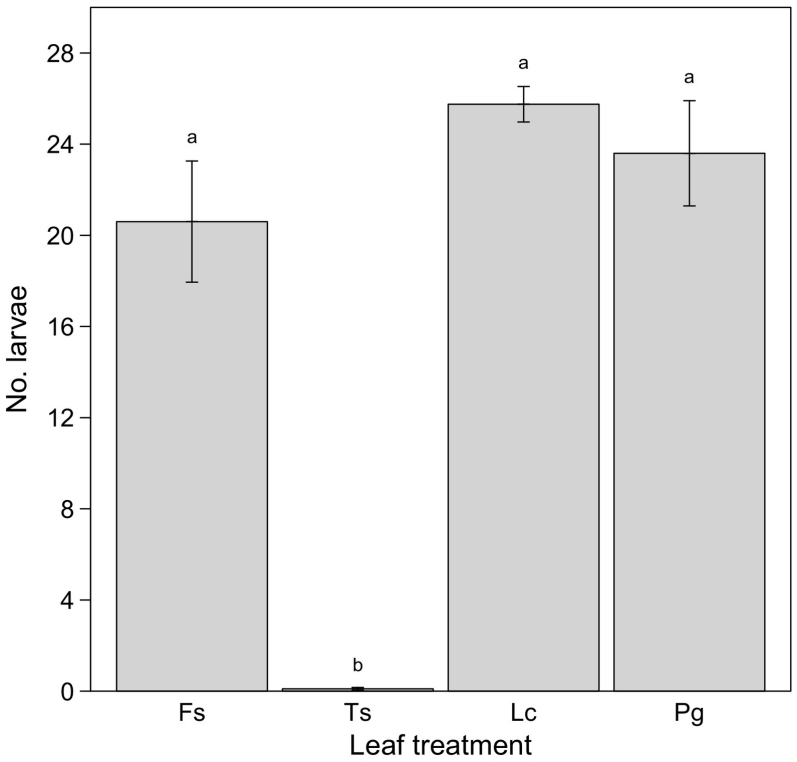

Figure 1 


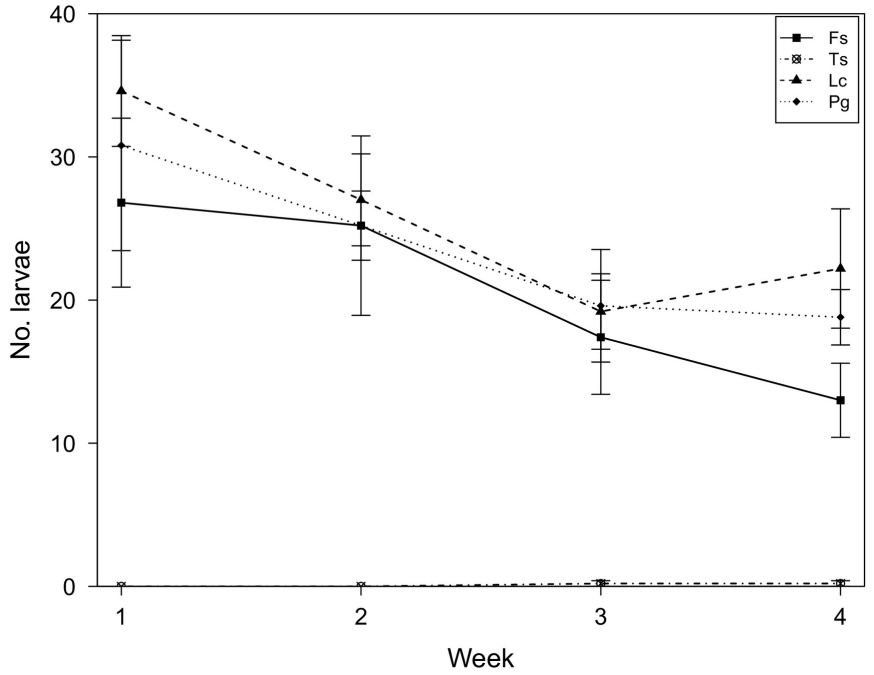

Figure 2 